\title{
COMBINED EFFECT OF TILLAGE AND SOWING METHODS ON RICE-WHEAT PRODUCTIVITY
}

\author{
KAHLON, M. S. ${ }^{*}-$ DHINGRA, M. \\ Department of Soil Science, Punjab Agricultural University, Ludhiana 141004, Punjab, India \\ *Corresponding author \\ e-mail:dr.mskahlon@rediffmail.com
}

(Received 23 ${ }^{\text {rd }}$ Apr 2019; accepted $16^{\text {th }}$ Jul 2019)

\begin{abstract}
Crop establishment methods and tillage practices significantly influence crop productivity by altering soil physical environment, root distribution and plant growth. The present study includes a combination of tillage practices for both rice and wheat i.e. deep tillage before rice (DTR) as well as wheat (DTW) along with conventional tillage before rice and wheat (CTRW) in main plots. The crop establishment methods i.e. no-tillage with residue (NTR) in wheat and direct seeded rice (DSR) were practiced in sub plots. These treatments were compared with traditional practices i.e. conventional tillage in wheat (CTW) and puddled transplanting in rice (PTR). It was reported that DTR and DTW results in $8 \%$ and $12 \%$ higher grain yields of rice and wheat, respectively over CTRW. Irrespective of crop establishment methods followed in rice, the NTR in wheat results in 7\% higher wheat grain yield than CTW. The reduced soil mechanical resistance under deep tillage resulted in $18 \%$ and $22 \%$ more root length densities of rice and wheat than CT. Thus, among tillage practices, DTR and DTW and among crop establishment methods PTR and NTR are appropriate practices for sustaining crop productivity of rice-wheat systems in northwest India.
\end{abstract}

Keywords: penetration resistance, deep tillage, direct seeding, puddled transplanting, water productivity

\section{Introduction}

Rice-wheat is a prominent cropping system of Northwest India. The commonly followed practice in rice cultivation is puddled transplanting and for wheat it is conventional tillage (CT). These conventional practices are leading to soil degradation, poor productivity and environmental risks. For sustaining crop and water productivity of rice-wheat system, new tillage practices along with crop establishment methods need to be studied. No doubt puddling controls weed, reducing deep percolation losses of nutrients and water, but it also causes soil structural breakdown and create hard pan at shallow soil depth, which hinders root and water penetration and also cause poor aeration for succeeding wheat crop. Since, wheat is a deep rooted crop and requires favorable soil conditions without compaction for proper root proliferation. Many researchers have reported adverse effect of puddling on the yield of a subsequent wheat crop (Arora et al., 2006; Farooq et al., 2008; Gangwar et al., 2004). Sharma et al. (2003) noted that the negative effect of puddling on wheat is more pronounced in medium- to fine-textured soils than in light-textured soils. Ishaq et al. (2001) observed that subsoil compaction resulted in a reduction of both water and nutrient use efficiency in wheat by $38 \%$ owing to decreased root length. Unproductive losses of water in traditional rice cultivation resulted in alarming fall in water table that threatens sustainability of rice production. This fall has resulted in increased energy requirement and cost of pumping groundwater, increased tube well installation cost and deteriorated the ground water quality (AICRP, 2009; Kamra et al., 2002). Thus, there is a need to explore alternate techniques that can sustain rice production and are resource conservative. The underground water is being over exploited by excessive pumping to meet the water 
requirement of transplanted rice. As a consequence, it has been causing a sharp decline in ground water table. Therefore, need has been felt to develop technically viable and economically feasible alternate techniques for growing rice in this region. The preliminary research conducted at Punjab Agricultural University indicated that DSR could be a viable alternative to PTR. The DSR offers many advantages such as more efficient water use, high tolerance to water deficit, less methane gas emission, reduced cultivation cost, prevents the formation of hard pan in sub-soil and minimizes labour input (Balasubramanian and Hill, 2002). It is more conducive to mechanization and also eliminates transplanting shock. However, the rice yield in most cases was higher (8$80 \%$ ) under puddled transplanted rice (PTR) than under direct seeder rice (DSR). Other studies reported no difference in yield of rice under both crop establishment methods (Bajpai and Tripathi, 2000; Hobbs et al., 2002; Sharma et al., 1995, 2005). In India, yields were significantly lower (9-28\%) in DSR than in PTR. However, DSR has several advantageous in poorly drained areas, it can be established earlier than PTR and does not incur growth delays from transplant injury; hence, it may hasten physiological maturity, reducing vulnerability to late-season drought (Tuong et al., 2000). Naklang et al. (1996) note that DSR had more root biomass than PTR. Some findings suggest that DSR achieves higher tiller density, leaf area, and vegetative biomass (Dingkuhn et al., 1990; Schnier et al., 1990), and that yields match or exceed PTR (Naklang et al., 1996; Saleh and Bhuiyan, 1995). Cultural practices like deep tillage in advance of soil puddling attempt to preserve the advantages of PTR while expanding the rooting zone above the plough sole. Akhtar and Quereshi (1999) found a depth-wise increase in root distribution from 12 to $20 \mathrm{~cm}$ and a yield benefit of $30 \%$ with adoption of deep tillage prior to PTR. By contrast, deep tillage preceding DSR may breech pre-existing plough soles, potentially exacerbating hazards posed by drought, weeds, and nutrient deficiencies from changes to the field water balance. As soil water dynamics in DSR is different from that of PTR, this is likely to affect water and nutrient uptake, and ensuing growth and crop yields. In semi-arid subtropical climatic conditions, DSR is expected to respond to changes in soil physical environment caused by deep tillage resulting in improved crop productivity. Deep tillage has emerged as a better option to improve deep root growth (advantageous for water extraction during drought in upland rice) of rice cultivars. Tillage under intensive cropping system has the additional challenges of ensuring high water use, nutrient use and energy use efficiencies through deeper and denser crop rooting (Gajri et al., 2002). The deep tillage before wheat also helps in enhancing root proliferation and enabling the plant to explore water and nutrient from deeper layers. Since, management of huge quantity of paddy straw produced every year is a serious problem in the region. Its management through no-tillage and surface residue retention (NTR) is another viable option for sustaining productivity. Keeping these points in view, a field study was conducted on sandy loam soil with the objective to evaluate impact of deep tillage on rice-wheat productivity under two crop establishment methods as DSR and PTR in rice and NTR and CT in wheat, respectively.

\section{Materials and methods}

\section{Study area}

This field experiment was conducted at the Research farm of Department of Soil Science, Punjab Agricultural University, Ludhiana. The site represent the Indo-gangetic alluvial plains situated at $30^{\circ} 56^{\prime} \mathrm{N}$ latitude and $75^{\circ} 52^{\prime} \mathrm{E}$ longitudes with an altitude of 
$247 \mathrm{~m}$ above the mean sea level. The area is characterized by sub-tropical and semi-arid type of climate with hot and dry summer from April to June followed by hot and humid period during July to September and cold winters from November to January. The summer temperature touches $45{ }^{\circ} \mathrm{C}$ with dry summer spells. Winter experiences frequent frosty spells especially in December and January and minimum temperature dips up to $0.5^{\circ} \mathrm{C}$. The climatic data of study period is presented in Figure 1. The experiment comprised of three main tillage practices namely deep tillage before rice (DTR), deep tillage before wheat (DTW) and conventional tillage in both rice and wheat (CTRW). While, two methods of crop establishment for rice i.e. puddled transplanted rice (PTR) and direct seeded rice (DSR) and two methods of sowing for wheat i.e. no-tillage with residue (NTR) and conventional tillage (CT) kept in sub plots. The experiment was replicated thrice with plot dimensions of $4.0 \mathrm{~m}$ width and $10.0 \mathrm{~m}$ length. In CT plots the field was disked twice followed by two cultivators and one planking operation while in DT the field was deep ploughed up to $45 \mathrm{~cm}$ depth with $50 \mathrm{~cm}$ apart and then CT operations were performed for conventional till plots and only deep till operation was performed where, wheat has to be sown by no till practice. In NTR the sowing of wheat was made directly under no-till conditions with retention of loose crop residue and standing rice stubbles in the field. In PTR the rice seedlings of 30 day old nursery were transplanted in field, while in DSR the wet rice seed was sown directly with drill. The sole DT operation was performed even in no-tillage plots excluding all other CT practices i.e. disking, cultivator and planking operations. The soil was neutral, non calcareous in nature and sandy loam in texture (Typic Ustochrept). The data pertaining to physico-chemical characteristics of the studied soil is presented in Table 1. The sowing of DSR was performed following all recommended packages of practices in the first week of June, while PTR was transplanted in second week of June and wheat was sown in the first week of November. The row to row spacing was maintained as $20 \mathrm{~cm}$ in both rice and wheat. The harvesting of wheat and rice were performed in the month of April and October, respectively. The in-situ and laboratory determination were made for various soil physico-chemical characteristics at the end of the experiment.

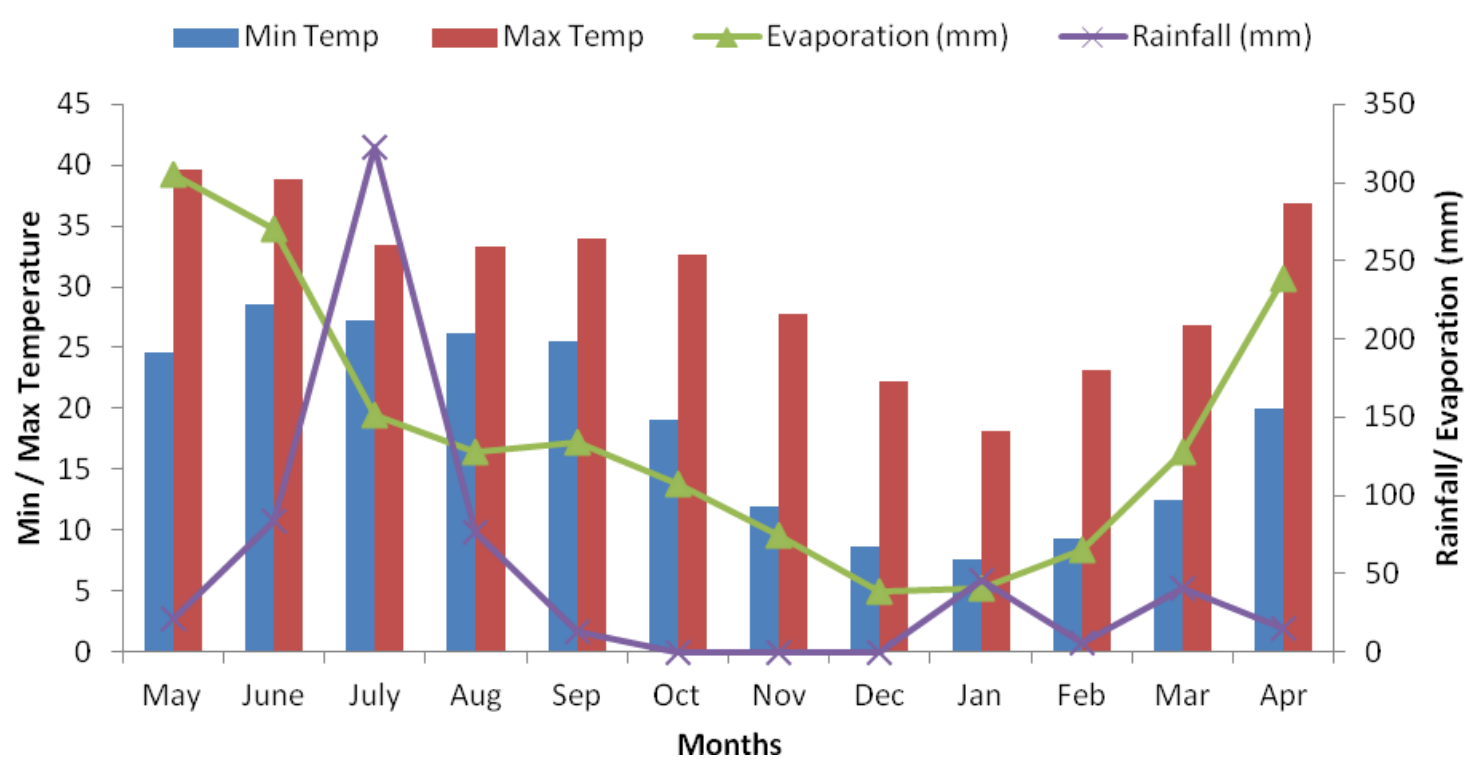

Figure 1. Climatic data for the study year 
Table 1. Soil parameters of experimental site

\begin{tabular}{|c|c|c|c|c|c|c|c|c|}
\hline \multirow{2}{*}{$\begin{array}{l}\text { Depth } \\
\text { (cm) }\end{array}$} & \multirow[t]{2}{*}{ pH } & \multirow{2}{*}{$\begin{array}{c}\mathrm{EC} \\
\left(\mathbf{d S} \mathrm{m}^{-1}\right)\end{array}$} & \multirow[t]{2}{*}{$\mathrm{OC}(\%)$} & \multirow{2}{*}{$\begin{array}{c}\text { BD } \\
\left(\mathrm{Mg} \mathrm{m}^{-3}\right)\end{array}$} & \multicolumn{2}{|c|}{$\begin{array}{c}\text { Soil water content } \\
(\%)\end{array}$} & \multirow[t]{2}{*}{ Sand $(\%)$} & \multirow[t]{2}{*}{ Clay (\%) } \\
\hline & & & & & FC & PWP & & \\
\hline $0-10$ & 8.46 & 0.38 & 0.42 & 1.44 & 20.9 & 9.8 & 68.5 & 19.7 \\
\hline $10-20$ & 8.33 & 0.29 & 0.31 & 1.53 & 22.1 & 10.3 & 63.2 & 22.8 \\
\hline $20-30$ & 8.30 & 0.23 & 0.24 & 1.62 & 24.4 & 11.8 & 60.6 & 24.6 \\
\hline $30-40$ & 8.24 & 0.19 & 0.21 & 1.57 & 26.7 & 12.6 & 58.3 & 25.7 \\
\hline $40-50$ & 8.21 & 0.16 & 0.21 & 1.53 & 27.3 & 13.7 & 54.7 & 27.8 \\
\hline
\end{tabular}

$\mathrm{EC}=$ electrical conductivity; $\mathrm{OC}=$ organic carbon; $\mathrm{BD}=$ bulk density, $\mathrm{FC}=$ field capacity; $\mathrm{PWP}=$ permanent wilting point

\section{Soil properties measurement}

The in-situ determination of soil bulk density $\left(\rho_{b}\right)$ was made with the help of cylindrical core having $7.5 \mathrm{~cm}$ height and $8.0 \mathrm{~cm}$ diameter at $0-15$ and $15-30 \mathrm{~cm}$ depth. The cores were dried in an oven at $105^{\circ} \mathrm{C}$ till the weight of the soil becomes constant. As given in Equation 1, the ratio of dry soil mass $\left(\mathrm{M}_{\mathrm{s}}\right)$ and internal volume $\left(\mathrm{V}_{\mathrm{t}}\right)$ of the cylindrical ring is expressed as $\rho_{b}$ of soil $\left(\mathrm{Mg} \mathrm{m}^{-3}\right)$ (Blake and Hartge, 1986).

$$
\mathrm{BD}=\mathrm{Ms} / \mathrm{Vt}
$$

The penetration resistance (PR) of soil was measured with hand-held digital cone penetrometer (CP40II; Rimik electronics, RFM Australia) at five randomly selected locations within a plot. The soil PR was recorded up to $60 \mathrm{~cm}$ depth.

Soil infiltration rate was determined using double ring infiltrometer method while the saturated hydraulic conductivity $\left(K_{s}\right)$ was determined using constant head method (Reynolds et al., 2002). For $K_{s}$ determination undisturbed soil cores (8 cm diameter and $7.5 \mathrm{~cm}$ length) were collected from 0-7.5 and 7.5-15 cm depth. Samples were saturated in the laboratory. Saturated soil sample along with core was connected with another core and to avoid the water leakage grease was applied in the jointing place on the top of previous core. A thin layer of water was slowly poured on top of the sample by using siphons connected to a constant head device (Mariotte apparatus). The volume of water that percolates through the sample was measured at definite intervals of time. The $K_{s}$ was calculated using Equation 2.

$$
K s=\mathrm{Q} \times \mathrm{L} / \mathrm{A} \times \mathrm{t}(\mathrm{H}+\mathrm{L})
$$

where: $K s=$ saturated hydraulic conductivity $\left(\mathrm{cm} \mathrm{hr}^{-1}\right) ; \mathrm{Q}=$ volume of percolate collected $\left(\mathrm{cm}^{3}\right) ; \mathrm{L}=$ length of soil column $(\mathrm{cm}) ; \mathrm{A}=$ cross sectional area of soil column $\left(\mathrm{cm}^{2}\right) ; \mathrm{t}=$ time $(\mathrm{hr}) ; \mathrm{H}=$ depth of water above soil $(\mathrm{cm})$.

\section{Determination of plant parameters, crop and water productivity}

During the crop growing period of both the crops the agronomic data on plant height, straw and grain yield was recorded. The grain yield of both the crops were recorded in $\mathrm{kg}$ from $24 \mathrm{~m}^{2}$ area in each plot and finally expressed in $\mathrm{t} \mathrm{ha}^{-1}$. The root distribution was measured at 120 days after sowing (DAS) in both rice and wheat, respectively. The root 
samples were collected up to $40 \mathrm{~cm}$ depth in rice and $70 \mathrm{~cm}$ depth in wheat. For root sampling, the soil cores were taken with the help of core sampler of $5 \mathrm{~cm}$ diameter. Samples were taken in between the plant rows. The root-soil cores were then collected and washed in plastic nets. Roots were carefully separated from the soil by washing the nets under water. The washed roots were further cleaned to remove any leftover weed roots, seed and other organic debris. The root length density (RLD) $\left(\mathrm{cm} \mathrm{cm}^{-3}\right)$ was calculated from the total length of roots measured by scanner to the volume of the core.

The water productivity (WP) was calculated by dividing the grain yield of corresponding treatment with the total water use (IW + RF + PWU) in particular treatment.

IW = amount of irrigation water applied $(\mathrm{cm})$

$\mathrm{RF}=$ rainfall during crop growth period $(\mathrm{cm})$

PWU $=$ profile water use $(\mathrm{cm})$

The data collected on various aspects of the investigations were statistically analysed as prescribed by Cochran and Cox (1967) and adapted by Cheema and Singh (1991) in statistical package CPCS-I. The treatment comparisons were made at 5\% level of significance.

\section{Results}

\section{Land management impacts on soil mechanical and water transmission characteristics}

Result revealed that soil bulk density (BD) was significantly influenced by tillage and crop establishment methods at both 0-15 and 15-30 cm soil depth (Table 2). Minimum soil BD $\left(\mathrm{Mg} \mathrm{m}^{-3}\right)$ was recorded in DTW (1.53) followed by DTR (1.55) and maximum in CTRW (1.58) at 0-15 cm depth. Similar trend was observed for $15-30 \mathrm{~cm}$ depth. Among crop establish methods, lesser mean BD was recorded under DSR as compared to PTR for both the depth. Among combination of treatments the PTR-CT results in maximum BD $\left(1.58 \mathrm{Mg} \mathrm{m}^{-3}\right)$, while DSR-NTR records minimum BD $\left(1.53 \mathrm{Mg} \mathrm{m}^{-3}\right)$. However, these effects were found to be non significant (Table 2). The data pertaining to effect of tillage on mean penetration resistance (PR) is presented in Figure 2.

Table 2. Effect of tillage practices and crop established methods on soil bulk density $\left(\mathrm{Mg} \mathrm{m}^{-3}\right)$ at $0-15$ and $15-30 \mathrm{~cm}$ soil depth

\begin{tabular}{|c|c|c|c|c|c|c|c|c|c|c|}
\hline \multirow{4}{*}{$\begin{array}{c}\text { Tillage } \\
\text { practices }\end{array}$} & \multicolumn{4}{|c|}{ Crop establishment methods } & \multirow{3}{*}{ Mean } & \multicolumn{4}{|c|}{ Crop establishment methods } & \multirow{3}{*}{ Mean } \\
\hline & \multicolumn{2}{|c|}{ DSR } & \multicolumn{2}{|c|}{ PTR } & & \multicolumn{2}{|c|}{ DSR } & \multicolumn{2}{|c|}{ PTR } & \\
\hline & NTR & CT & NTR & CT & & NTR & CT & NTR & CT & \\
\hline & \multicolumn{5}{|c|}{$(0-15 \mathrm{~cm})$} & \multicolumn{5}{|c|}{$(15-30 \mathrm{~cm})$} \\
\hline DTR & 1.53 & 1.54 & 1.56 & 1.57 & 1.55 & 1.64 & 1.66 & 1.68 & 1.71 & 1.67 \\
\hline DTW & 1.51 & 1.52 & 1.54 & 1.55 & 1.53 & 1.62 & 1.62 & 1.65 & 1.67 & 1.64 \\
\hline CTRW & 1.55 & 1.56 & 1.60 & 1.61 & 1.58 & 1.67 & 1.68 & 1.71 & 1.73 & 1.70 \\
\hline Mean & 1.53 & 1.54 & 1.57 & 1.58 & & 1.64 & 1.65 & 1.68 & 1.70 & \\
\hline $\begin{array}{c}\text { LSD } \\
(<0.05)\end{array}$ & \multicolumn{5}{|c|}{$\begin{array}{c}\text { Tillage }=0.03 \\
\text { Crop establishment } \text { methods }=0.02\end{array}$} & \multicolumn{5}{|c|}{$\begin{array}{c}\text { Tillage }=0.04 \\
\text { Crop establishment methods }=0.03\end{array}$} \\
\hline
\end{tabular}

$\mathrm{DTR}=$ Deep tillage before rice; $\mathrm{DTW}=$ Deep tillage before wheat; $\mathrm{CTRW}=$ Conventional tillage before rice and wheat; DSR $=$ direct seeded rice; PTR = puddled transplanted rice; NTR $=$ no-tillage with residue; $\mathrm{CT}=$ conventional tillage 


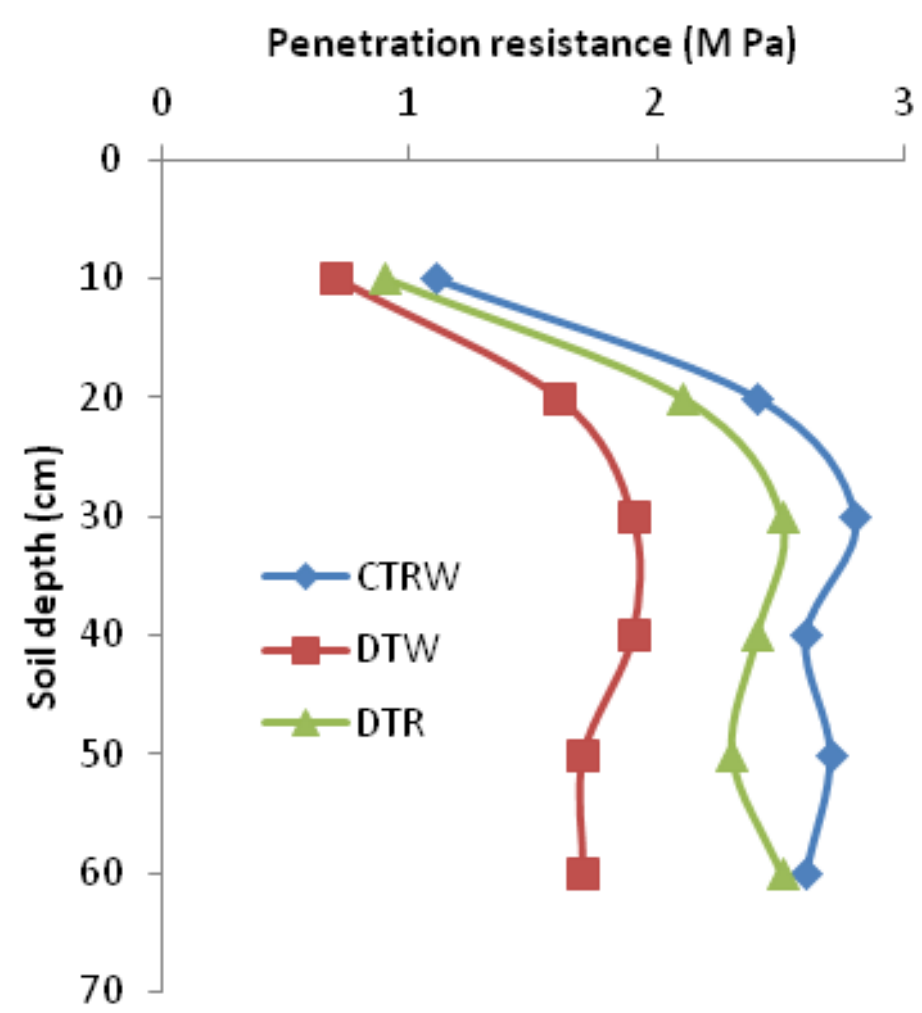

Figure 2. Soil penetration resistance under different tillage practices $(D T R=$ deep tillage before rice; $D T W=$ deep tillage before wheat; $C T R W=$ conventional tillage before rice and wheat)

The PR is a measure of soil strength and the force required by the plant root to penetrate into the soil pores. The penetration resistance of soil increased with increase in soil depth. Likewise soil BD, the PR was also found to be significantly affected by tillage practices i.e. lowest PR was recorded under DTW (1.7 M Pa) and maximum under CTRW (2.9 M pa) at $30 \mathrm{~cm}$ soil depth. The data pertaining to steady state infiltration rate (IR) under different tillage practices has been presented in Table 3.

Table 3. Effect of tillage practices and crop establishment methods on soil infiltration rate and saturated hydraulic conductivity $\left(\mathrm{cm} \mathrm{hr}^{-1}\right)$

\begin{tabular}{|c|c|c|c|c|c|c|c|c|c|c|}
\hline \multirow{4}{*}{$\begin{array}{c}\text { Main } \\
\text { tillage } \\
\text { practices }\end{array}$} & \multicolumn{4}{|c|}{ Crop establishment methods } & \multirow{3}{*}{ Mean } & \multicolumn{4}{|c|}{ Crop establishment methods } & \multirow{3}{*}{ Mean } \\
\hline & \multicolumn{2}{|c|}{ DSR } & \multicolumn{2}{|c|}{ PTR } & & \multicolumn{2}{|c|}{ DSR } & \multicolumn{2}{|c|}{ PTR } & \\
\hline & NTR & CT & NTR & CT & & NTR & CT & NTR & CT & \\
\hline & \multicolumn{5}{|c|}{ Infiltration rate $\left(\mathrm{cm} \mathrm{hr}^{-1}\right)$} & \multicolumn{5}{|c|}{ Saturated hydraulic conductivity $\left(\mathrm{cm} \mathrm{hr}^{-1}\right)$} \\
\hline DTR & 1.4 & 1.1 & 1.1 & 0.8 & 1.1 & 1.8 & 1.5 & 1.6 & 1.4 & 1.6 \\
\hline DTW & 1.7 & 1.5 & 1.4 & 1.1 & 1.4 & 2.1 & 1.7 & 1.6 & 1.5 & 1.7 \\
\hline CTRW & 1.1 & 0.8 & 0.9 & 0.7 & 0.9 & 1.6 & 1.2 & 1.4 & 1.2 & 1.4 \\
\hline Mean & 1.4 & 1.1 & 1.1 & 0.9 & & 1.8 & 1.5 & 1.5 & 1.4 & \\
\hline $\begin{array}{c}\text { LSD } \\
(<0.05)\end{array}$ & \multicolumn{5}{|c|}{$\begin{array}{c}\text { Tillage }=0.4 \\
\text { Crop establishment } \text { methods }=0.3\end{array}$} & \multicolumn{5}{|c|}{$\begin{array}{c}\text { Tillage }=0.3 \\
\text { Crop establishment } \text { methods }=0.3\end{array}$} \\
\hline
\end{tabular}

$\mathrm{DTR}=$ Deep tillage before rice; $\mathrm{DTW}=$ Deep tillage before wheat; $\mathrm{CTRW}=$ Conventional tillage before rice and wheat; DSR = direct seeded rice; PTR = puddled transplanted rice; NTR = no-tillage with residue; $\mathrm{CT}=$ conventional tillage 
The steady state IR was higher under DTW $\left(1.4 \mathrm{~cm} \mathrm{hr}^{-1}\right)$ followed by DTR $\left(1.1 \mathrm{~cm} \mathrm{hr}^{-1}\right)$ and least in CTRW $\left(0.9 \mathrm{~cm} \mathrm{hr}^{-1}\right)$. However, among crop establishment methods higher mean IR was recorded in DSR than PTR. Likewise infiltration rate, maximum saturated hydraulic conductivity was recorded in DTW $\left(1.7 \mathrm{~cm} \mathrm{hr}^{-1}\right)$ followed by DTR $\left(1.6 \mathrm{~cm} \mathrm{hr}^{-1}\right)$ and least in CTRW $\left(1.4 \mathrm{~cm} \mathrm{hr}^{-1}\right)$. Among crop establishment methods maximum saturated hydraulic conductivity was recorded in DSR-NTR $\left(1.8 \mathrm{~cm} \mathrm{hr}^{-1}\right)$ and minimum in PTR-CT $\left(1.4 \mathrm{~cm} \mathrm{hr}^{-1}\right)$.

\section{Plant height and root distribution}

Data pertaining to plant height under different land management practices is presented in Table 4. The data revealed that, plant height significantly affected both by tillage and crop establishment methods. Maximum rice plant height was recorded in PTR-CT $(102.8 \mathrm{~cm})$ and least in DSR-HS $(100.1 \mathrm{~cm})$. Among main tillage practices, significantly higher rice mean plant height was recorded in DTR $(103.0 \mathrm{~cm})$ followed by DTW $(101.3 \mathrm{~cm})$ and lowest in CTRW $(99.8 \mathrm{~cm})$. In wheat also, the DTW recorded significantly higher plant height $(104.0 \mathrm{~cm})$ followed by DTR $(102.3 \mathrm{~cm})$ and least in CTRW $(100.1 \mathrm{~cm})$. However, among crop establishment methods maximum wheat mean plant height was observed in NTR-PTR $(103.2 \mathrm{~cm})$ and least in CT-DSR $(100.7 \mathrm{~cm})$. The mean root length density (RLD) of rice differed significantly under various tillage and crop establishment methods at different soil depths. The mean rice RLD in surface soil layer $(10 \mathrm{~cm})$ was 16 percent higher under DTR-PTR than DTRCTRW (Fig. 3). However, at lower soil depths i.e. 20, 3040 and $50 \mathrm{~cm}$ the RLD was observed to be $33 \%, 43 \%, 23 \%$ and $17 \%$ higher under DTR-DSR than CTRW, respectively.

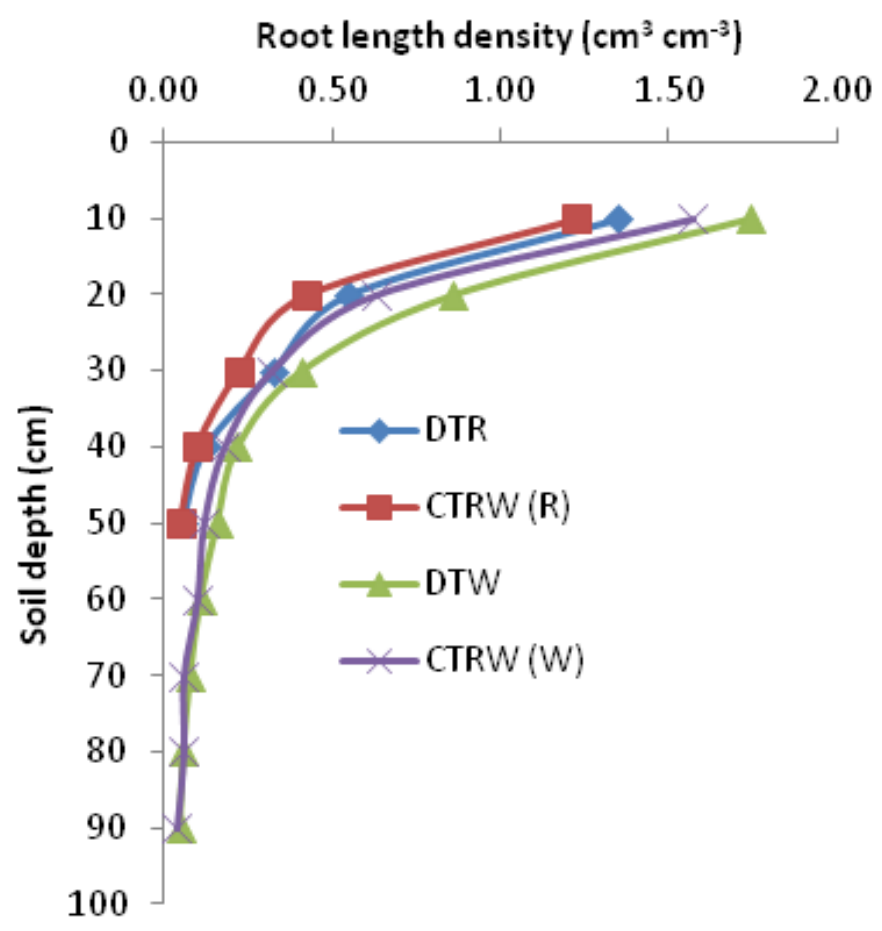

Figure 3. Rice root length densities of rice and wheat under different tillage practices $(D T R=$ deep tillage before rice; $D T W=$ deep tillage before wheat $; C T R W(R)=$ conventional tillage before rice and wheat for rice root; $C T R W(W)=$ conventional tillage before rice and wheat for wheat 
Table 4. Effect of tillage practices and crop establishment methods on plant height of rice and wheat

\begin{tabular}{|c|c|c|c|c|c|c|c|c|c|c|}
\hline \multirow{4}{*}{$\begin{array}{c}\text { Tillage } \\
\text { practices }\end{array}$} & \multicolumn{4}{|c|}{ Crop establishment methods } & \multirow{3}{*}{ Mean } & \multicolumn{4}{|c|}{ Crop establishment methods } & \multirow{3}{*}{ Mean } \\
\hline & \multicolumn{2}{|c|}{ DSR } & \multicolumn{2}{|c|}{ PTR } & & \multicolumn{2}{|c|}{ DSR } & \multicolumn{2}{|c|}{ PTR } & \\
\hline & NTR & CT & NTR & CT & & NTR & CT & NTR & CT & \\
\hline & \multicolumn{5}{|c|}{ Rice plant height (cm) } & \multicolumn{5}{|c|}{ Wheat plant height $(\mathrm{cm})$} \\
\hline DTR & 101.2 & 102.6 & 103.3 & 104.8 & 103.0 & 102.8 & 101.5 & 102.7 & 102.2 & 102.3 \\
\hline DTW & 100.3 & 100.7 & 101.7 & 102.6 & 101.3 & 103.6 & 102.1 & 105.8 & 104.7 & 104.0 \\
\hline CTRW & 98.9 & 99.3 & 100.4 & 100.9 & 99.8 & 100.3 & 98.4 & 101.2 & 100.5 & 100.1 \\
\hline Mean & 100.1 & 100.9 & 101.8 & 102.8 & & 102.2 & 100.7 & 103.2 & 102.5 & \\
\hline $\begin{array}{l}\text { LSD } \\
(<0.05)\end{array}$ & \multicolumn{5}{|c|}{$\begin{array}{c}\text { Tillage }=1.3 \\
\text { Crop establishment } \text { methods }=0.9\end{array}$} & \multicolumn{5}{|c|}{$\begin{array}{c}\text { Tillage }=1.6 \\
\text { Crop establishment methods }=1.1\end{array}$} \\
\hline
\end{tabular}

DTR $=$ Deep tillage before rice; DTW $=$ Deep tillage before wheat; $\mathrm{CTRW}=$ Conventional tillage before rice and wheat; DSR $=$ direct seeded rice; PTR = puddled transplanted rice; NTR $=$ no-tillage with residue; $\mathrm{CT}=$ conventional tillage

\section{Crop and water productivity of rice and wheat}

The rice straw as well as grain yield was found to be significantly more under DTR (7.0 $\left.\mathrm{t} \mathrm{ha}^{-1}\right)$ followed by DTW $\left(6.7 \mathrm{t} \mathrm{ha}^{-1}\right)$ and least in CTRW $\left(6.4 \mathrm{t} \mathrm{ha}^{-1}\right)$. Among crop establishment methods maximum rice straw yield was recorded in PTR-CT (7.5 t ha $\left.{ }^{-1}\right)$ and minimum in DSR-HS $\left(5.9 \mathrm{t} \mathrm{ha}^{-1}\right)$. Similarly maximum rice grain yield was recorded in DTR (6.1 t ha-1) and minimum in CTRW (5.6 $\mathrm{t} \mathrm{ha}^{-1)}$ (Table 5).

Table 5. Effect of tillage practices and crop establishment methods on rice straw and grain yield (t/ha)

\begin{tabular}{|c|c|c|c|c|c|c|c|c|c|c|}
\hline \multirow{4}{*}{$\begin{array}{l}\text { Tillage } \\
\text { practices }\end{array}$} & \multicolumn{4}{|c|}{ Crop establishment methods } & \multirow{3}{*}{ Mean } & \multicolumn{4}{|c|}{ Crop establishment methods } & \multirow{3}{*}{ Mean } \\
\hline & \multicolumn{2}{|c|}{ DSR } & \multicolumn{2}{|c|}{ PTR } & & \multicolumn{2}{|c|}{ DSR } & \multicolumn{2}{|c|}{ PTR } & \\
\hline & NTR & CT & NTR & CT & & NTR & CT & NTR & $\mathbf{C T}$ & \\
\hline & \multicolumn{5}{|c|}{ Rice straw yield (t/ha) } & \multicolumn{5}{|c|}{ Rice grain yield (t/ha) } \\
\hline DTR & 6.1 & 6.7 & 7.2 & 7.8 & 7.0 & 5.4 & 5.9 & 6.3 & 6.7 & 6.1 \\
\hline DTW & 5.9 & 6.5 & 6.9 & 7.5 & 6.7 & 5.4 & 5.7 & 6.1 & 6.4 & 5.9 \\
\hline CTRW & 5.7 & 6.0 & 6.5 & 7.2 & 6.4 & 5.1 & 5.4 & 5.6 & 6.1 & 5.6 \\
\hline Mean & 5.9 & 6.4 & 6.9 & 7.5 & & 5.3 & 5.7 & 6.0 & 6.4 & \\
\hline $\begin{array}{l}\text { LSD } \\
(<0.05)\end{array}$ & \multicolumn{5}{|c|}{$\begin{array}{c}\text { Tillage }=0.3 \\
\text { Crop establishment } \text { methods }=0.6\end{array}$} & \multicolumn{5}{|c|}{$\begin{array}{c}\text { Tillage }=0.4 \\
\text { Crop establishment } \text { methods }=0.5\end{array}$} \\
\hline
\end{tabular}

$\mathrm{DTR}=$ Deep tillage before rice; DTW $=$ Deep tillage before wheat; $\mathrm{CTRW}=$ Conventional tillage before rice and wheat; DSR $=$ direct seeded rice; PTR $=$ puddled transplanted rice; NTR $=$ no-tillage with residue; $\mathrm{CT}=$ conventional tillage

Among crop establishment methods maximum rice grain yield was recorded in PTR-CT $\left(6.4 \mathrm{t} \mathrm{ha}^{-1}\right)$ and minimum in DSR-HS $\left(5.3 \mathrm{t} \mathrm{ha}^{-1}\right)$. In wheat, maximum straw yield was recorded in DTW (5.9 $\left.\mathrm{t} \mathrm{ha}^{-1}\right)$ and minimum in CTRW (5.3 $\left.\mathrm{t} \mathrm{ha}^{-1}\right)$. Among crop establishment methods maximum wheat straw yield was recorded in PTR-NTR $\left(6.1 \mathrm{tha}^{-1}\right)$ and minimum in DSR-CT $\left(5.1 \mathrm{t} \mathrm{ha}^{-1}\right)$. Grain yield of wheat was also observed to be highest in DTW (5.2 $\left.\mathrm{t} \mathrm{ha}^{-1}\right)$ and least in CTRW (4.6 $\left.\mathrm{t} \mathrm{ha}^{-1}\right)$ (Table 6). The 
DTR-NTR out yielded wheat productivity by $14 \%$ than DSR-CT. The water productivity of rice and wheat was found to be significantly affected by tillage practices and crop establishment methods. Maximum WP in rice was recorded in DTR (5.35 $\mathrm{kg} \mathrm{ha}^{-1} \mathrm{~mm}^{-1}$ ) and least in CTRW (3.92 $\mathrm{kg} \mathrm{ha}^{-1} \mathrm{~mm}^{-1}$ ) (Fig. 4). However, among crop establishment methods the maximum WP was recorded in PTR-CT followed by PTR-NTR, DSR-CT and least in DSR-NTR. Similarly, in wheat, maximum WP was observed in DTW (15.14 kg ha-1 $\left.\mathrm{mm}^{-1}\right)$ and least in DSR-CT (13.24 $\left.\mathrm{kg} \mathrm{ha}^{-1} \mathrm{~mm}^{-1}\right)$ (Fig. 5). Under crop establishment methods the maximum WP was recorded under NTR-PTR followed by CT-PTR, NTR-DSR and least in CT-DSR.

Table 6. Effect of tillage practices and crop establishment methods on wheat straw and grain yield $(t / h a)$

\begin{tabular}{|c|c|c|c|c|c|c|c|c|c|c|}
\hline \multirow{4}{*}{$\begin{array}{l}\text { Tillage } \\
\text { practices }\end{array}$} & \multicolumn{4}{|c|}{ Crop establishment methods } & \multirow{3}{*}{ Mean } & \multicolumn{4}{|c|}{ Crop establishment methods } & \multirow{3}{*}{ Mean } \\
\hline & \multicolumn{2}{|c|}{ DSR } & \multicolumn{2}{|c|}{ PTR } & & \multicolumn{2}{|c|}{ DSR } & \multicolumn{2}{|c|}{ PTR } & \\
\hline & NTR & CT & NTR & CT & & NTR & CT & NTR & CT & \\
\hline & \multicolumn{5}{|c|}{ Wheat straw yield (t/ha) } & \multicolumn{5}{|c|}{ Wheat grain yield (t/ha) } \\
\hline DTR & 5.3 & 5.1 & 6.0 & 5.8 & 5.6 & 4.6 & 4.4 & 5.1 & 4.8 & 4.7 \\
\hline DTW & 5.6 & 5.3 & 6.4 & 6.1 & 5.9 & 5.1 & 4.9 & 5.6 & 5.3 & 5.2 \\
\hline CTRW & 5.2 & 4.8 & 5.8 & 5.4 & 5.3 & 4.5 & 4.2 & 4.9 & 4.7 & 4.6 \\
\hline Mean & 5.4 & 5.1 & 6.1 & 5.8 & & 4.7 & 4.5 & 5.2 & 4.9 & \\
\hline $\begin{array}{c}\mathrm{LSD} \\
(<0.05)\end{array}$ & \multicolumn{5}{|c|}{$\begin{array}{c}\text { Tillage }=0.2 \\
\text { Crop establishment methods }=0.5\end{array}$} & \multicolumn{5}{|c|}{ isnme } \\
\hline
\end{tabular}

$\mathrm{DTR}=$ Deep tillage before rice; $\mathrm{DTW}=$ Deep tillage before wheat $\mathrm{CTRW}=$ Conventional tillage before rice and wheat; DSR $=$ direct seeded rice; PTR = puddled transplanted rice; NTR $=$ no-tillage with residue; $\mathrm{CT}=$ conventional tillage

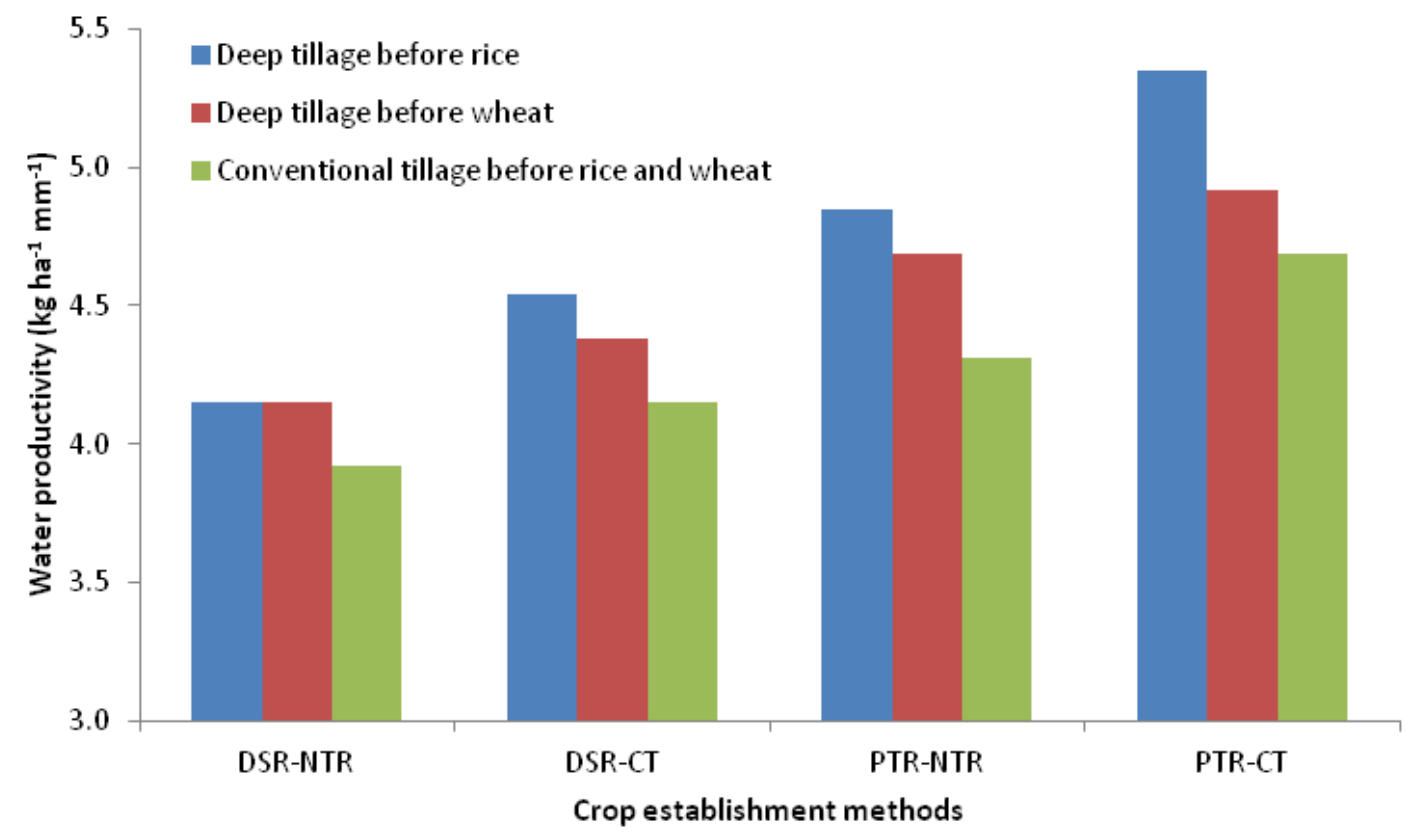

Figure 4. Water productivity of rice under different tillage practices and crop establishment method $(D S R=$ direct seeded rice; $P T R=$ puddled transplanted rice; $N T R=$ no-tillage with residue; $C T=$ conventional tillage) 


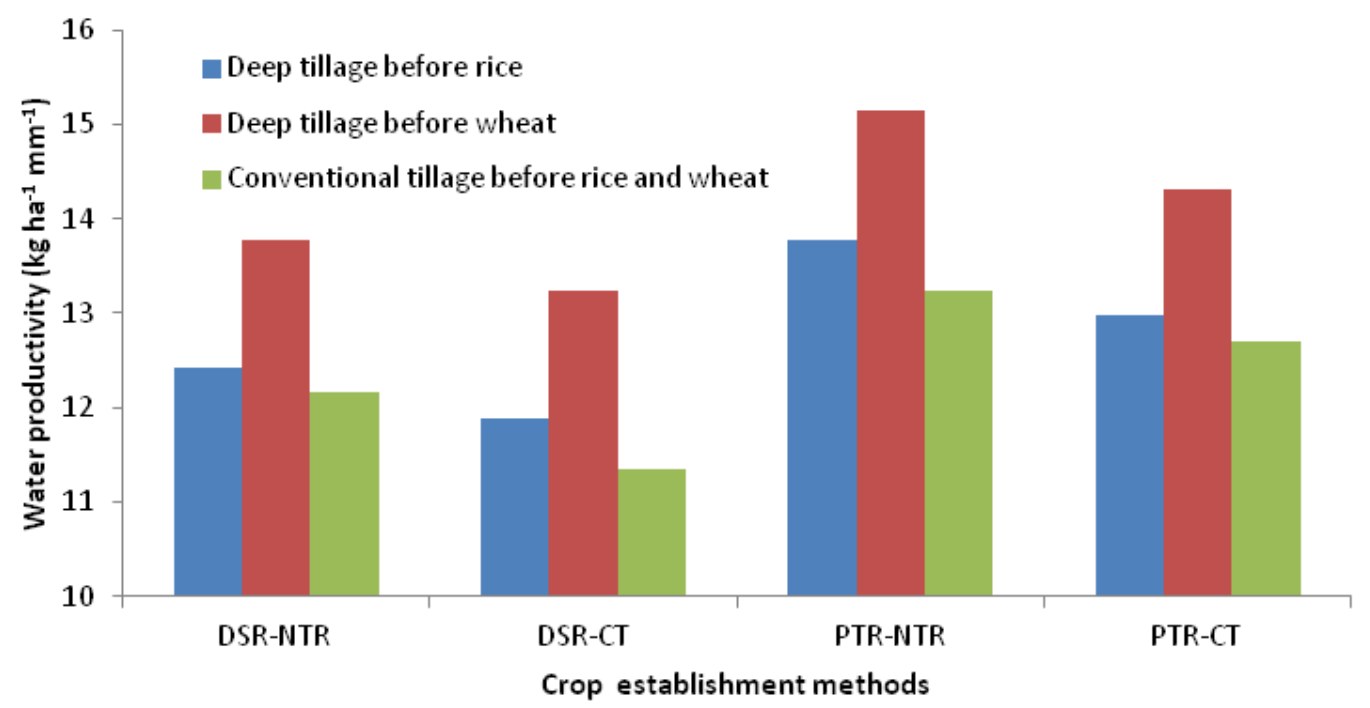

Figure 5. Water productivity of wheat under different tillage practices and crop establishment method $(D S R=$ direct seeded rice; $P T R=$ puddled transplanted rice $; N T R=$ no-tillage with residue; $C T=$ conventional tillage)

\section{Discussion}

\section{Effect of tillage and crop establishment methods on soil compaction and water transmission}

Conventional tillage practices including puddling in rice and performing five field operations for seed bed preparation in wheat have lead to destruction of soil structure by breaking macro aggregates into micro aggregates. Also due to physical compression there is formation of hard pan and increased bulk density at sub surface layer, which hinders growth of wheat roots to deeper depths. The bulk density of soil increases with the number of traffic passes and intensity whereas infiltration rate decreases with number of passes. However, with deep tillage practice due to shattering of soil up to $45 \mathrm{~cm}$ depth and $50 \mathrm{~cm}$ apart, the hard pan lying at $15-25 \mathrm{~cm}$ depth broken down leading to loosening of soil which further helps in increasing soil; water infiltration and saturated hydraulic conductivity of the soil. Among crop establishment the DSR showed lesser bulk density than PTR. This might be due to lesser number of field operations in DSR than PTR and also due to puddling and transplanting the chances of soil compaction increases as observed through higher bulk density and penetration resistance values. Prasad and Balanagoudar (2017) also reported lower soil bulk density in DSR than PTR as puddling resulted in destruction of soil aggregates and dispersion of soil particles to form compact layer having low porosity. Commonly all tillage practices accounts to reduced bulk density to the depth of tillage operation (Erbach et al., 1992; Osunbitan et al., 2005) and water infiltration rate was greater in tilled than notilled soil (Ferreras et al., 2000).

The water transmission characteristics of soil are also observed to be significantly affected by tillage and crop establishment methods. The various physical properties of soil such as bulk density, porosity and water holding capacity are fundamental indicators that show the effect of tillage on soils hydraulic properties (Strudley et al., 2008). The deep tillage improves soil properties by reducing soil bulk density and penetration resistance in the tilled layer (Varsa et al., 1997) and by altering soil porosity, 
increasing hydraulic conductivity and infiltration rate (Laddha and Totawat, 1997). Sojka et al. (1997) also found that deep tillage increases soil porosity, saturated and unsaturated hydraulic conductivity, improves the aeration status which leads to increased soil moisture storage (Velykis, 2004) in the loosened soil layer. Chan and Mead (1989) noticed that tilled soils exhibited greater hydraulic conductivities than untilled soils and attributed the difference to decreased soil bulk density and improved porosity than in soils under no tillage conditions. Higher infiltration rate recorded in DT than CT may be due to ample amount of macro pores which led to fast entry of water into the soil profile. Almouti et al. (2007) reported increase in infiltration rate with increase in tillage depth; the probable cause might be the decrease in bulk density.

\section{Effect of tillage and crop establishment on crop growth and productivity}

The deep tillage reduces the soil compaction, thereby increasing the water availability to the crops by facilitating well developed root system. Many reports over the world have shown that tillage practices influence root growth and crop yield by altering soil properties such as soil structure, water, aeration, fertility and other factors having strong influence on crop yield, water and fertilizer use efficiency of crops (Acharya and Sharma, 1994; Holanda et al., 1998; Lampurlanes and Cantero-Martinez, 2003). Cai et al. (2014) observed that DT to a soil depth of $50 \mathrm{~cm}$ have significantly improved root morphology and thereby increases the resistance to environmental stress. The various studies have reported that DT can increase the crop yield and resource use efficiency, largely due to the improved physical, biological, and hydraulic properties of the soil (Jabro et al., 2009). Further, soil manipulation and loosening by DT permits greater water movement and aeration in the soil, facilitates better root proliferation to deeper layers and allows the deeper chemical movement as compared to untilled soil (Diaz-Zorita, 2000; Strudley et al., 2008). High soil strength often limits the root proliferation to deeper layers and thus hinders the usage of water and nutrient resources (Bengough et al., 2011). The higher RLD under deep tilled conditions could be due to improved physical conditions of the soil which facilitates better root proliferation due to reduced mechanical resistance. The DSR do not perform well from productivity point of view. This may be due to higher weed infestation and iron deficiency. As above ground biomass is the function of the below ground biomass, i.e. root system. Better the root system more will be the exploration of soil volume by plant roots for water and nutrients, more will be the translocation of water and nutrients and hence the above ground biomass. Thus, higher grain yield was recorded under deep tillage than conventional tillage in both rice and wheat crops. However, among crop establishment methods, the PTR performed significantly better than DSR. The shallow and compacted topsoil in conventional tilled plots not only restricts the root development of plants, but hinders their absorption of nutrients and water (Wang et al., 2008). This could be due to the negative effect of residue retained on the following DSR crop. There was a consistent trend for poorer growth of DSR following wheat mulched with rice straw, suggesting the need to examine the possibility of allelopathic effects of surface rice straw retention in direct seeded rice-wheat systems (Gupta et al., 2016). The deep tillage reduces soil strength and soil bulk density (Laddha and Totawat, 1997), improves water storage in the soil, enhances the root growth (Holloway and Dexter, 1991) thereby increases crop production (Ghosh et al., 2006) as compared to conventional tillage. The crop productivity was higher under tillage depth of $35 \mathrm{~cm}$ as compared to tillage depth of $15 \mathrm{~cm}$ (Zhang and $\mathrm{Li}, 2010$ ). Sub-soil compaction reduced both the water and 
nutrient use efficiencies of wheat by about $38 \%$ in a fine loamy soil (Ishaq et al., 2001). Deep tillage (chiseling), decreases soil bulk density and penetration resistance of this compact layer, increases depth of rooting, profile water use and yield of following wheat crop. Mosaddeghi et al. (2009) found that soil conditions under a zero-tillage conservation system were better than those under conventional system in arid and semiarid environments. Residues accumulation in the soil acts as mulch which protects the soil from soil aggregate destruction enhances infiltration of water. It is an important organic source for retaining and improving soil fertility (Wang et al., 2002).

\section{Conclusion}

The deep tillage before wheat and rice improves crop and water productivity. Among crop establish methods puddled transplanted rice significantly improved rice yield and in wheat no-tillage with residue out yielded conventional tillage. The deep tillage provides healthy soil environment by reducing soil compaction and allowing water and roots to move to deeper soil layers. The greater root proliferation under deep tillage helps in extracting water and nutrient from lower soil depths. Thus, deep tillage helps in reducing mechanical strength and enhancing water transmission. Thus, in northwest Indian conditions in rice deep tillage along with puddled rice transplanting and in wheat, deep tillage along with no-tillage and residue are appropriate tillage and crop establishment techniques for enhancing crop and water productivity. However, further research needs to be carried out on impact of different tillage practices under variable irrigation and nitrogen regimes on cereals and pulse based cropping systems.

\section{REFERENCES}

[1] Acharya, C., Sharma, P. (1994): Tillage and mulch effects on soil physical environment, root growth, nutrient uptake and yield of maize and wheat on an Alfisol in north-west India. - Soil Till. Res. 32: 291-302.

[2] AICRP (2009): All India Coordinated Project on Management of salt Affected Soils and Use of Saline Water in Agriculture Biennial Report (2006-08). - Central Soil Salinity Research Institute, Karnal, Haryana, India.

[3] Akhtar, M. S., Quereshi, S. Q. (1999): Soil hydraulic properties and rice root development as influenced by tillage. - Pakistan J. Biol. Sci. 2(4): 1245-1251.

[4] Alamouti, M. Y., Navabzadeh, M. (2007): Investigation of plowing depth effect on some soil physical properties. - Pak J Biol Sci.10: 4540-14.

[5] Arora, V. K., Gajri, P. R., Uppal, H. S. (2006): Puddling, irrigation, and transplanting time effects on productivity of rice-wheat system on a sandy loam soil of Punjab, India. Soil Till. Res. 85: 212-220.

[6] Bajpai, R. K., Tripathi, R. P. (2000): Evaluation of non-puddling under shallow water tables and alternative tillage methods on soil and crop parameters in a rice-wheat system in Uttar Pradesh. - Soil Till. Res. 55: 99-106.

[7] Balasubramanian, V., Hill, J. E. (2002): Direct Seeding of Rice in Asia: Emerging Issues and Strategic Research Needs for the 21st Century. - In: Pandey, S., Mortimer, M., Wade, L., Tuong, T. P., Lopez, K., Hardy, B. (eds.) Direct Seeding: Research Strategies and Opportunities. International Rice Research Institute, Los Banos, Philippines, pp.1539.

[8] Bengough, A. G., McKenzie, B. M., Hallett, P. D., Valentine, T. A. (2011): Root elongation, water stress, and mechanical impedance: a review of limiting stresses and beneficial root tip traits. - J Exp Bot 62: 59-68. 
[9] Blake, G. R., Hartge, K. H. (1986): Bulk Density. - In: Klute, A. (ed.) Methods of Soil Analysis. ASA, Madison, WI, pp 363-75.

[10] Cai, H. G., Ma, W., Zhang, X. Z., Ping, J. Q., Yan, X. G., Liu, J. Z., Yuan, J. C., Wang, L. C., Ren, J. (2014): Effect of subsoil tillage depth on nutrient accumulation, root distribution, and grain yield in spring maize. - Crop J 2: 297-307.

[11] Chan, K. Y., Mead, J. A. (1989): Water movement and macroporosity of an Australian Alfisol under different tillage and pasture conditions. - Soil Till Res14: 301-10.

[12] Cheema, H. S., Singh, B. (1991): Software Statistical Package CPCS-1. - Department of Statistics, PAU, Ludhiana.

[13] Cochran, W. G., Cox, G. M. (1967): Experimental Designs. - John Wiley, New York.

[14] Diaz-Zorita, M. (2000): Effects of deep-tillage and nitrogen fertilization interactions on dryland corn (Zea mays L.) productivity. - Soil Till Res 54: 11-19.

[15] Dingkuhn, M., Schnier, H. F., DeDatta, S. K., Dorffling, K., Javellana, C., Pamplona, R. (1990): Nitrogen fertilization of direct seeded flooded vs. transplanted rice. II. Interactions among canopy properties. - Crop Sci. 30(6): 1284-1292.

[16] Erbach, D. C., Benjamin, J. G., Cruse, R. M., Elamin, M. A., Mukhtar, S., Choi, C. H. (1992): Soil and corn response to tillage with paraplow. - Transactions of the ASAE 35: 1347-1354.

[17] Farooq, M., Basra, S. M. A., Asad, S. A. (2008): Comparison of conventional puddling and dry tillage in rice-wheat system. - Paddy Water Environ. 6: 397-404.

[18] Ferreras, L. A., Costa, J. L., Garcia, F. O., Pecorari, C. (2000): Effect of no-tillage on some physical properties of structural degraded Petrocalcic Paleudoll of southern Pampa of Argentina. - Soil Till Res 54: 31-39.

[19] Gajri, P. R., Arora, V. K., Parihar, S. S. (2002): Tillage for Sustainable Cropping. - Food Products Press, New York.

[20] Gangwar, K. S., Singh, K. K., Sharma, S. K. (2004): Effects of tillage on growth, yield and nutrient uptake in wheat after rice in Indo-Gangetic Plains of India. - J. Agric. Sci. 142: 453-459.

[21] Ghosh, P. K., Mohanty, M., Bandyopadhyay, K. K., Painuli, D. K., Misra, A. K. (2006): Growth, competition, yield advantage and economics in soybean/pigeonpea intercropping system in semi-arid tropics of India: I. Effect of subsoiling. - Field Crops Res 96: 80-89.

[22] Gupta, N., Yadav, S., Humphreys, E., Kukal, S. S., Balwinder-Singh., Eberbach, P. L. (2016): Effects of tillage and mulch on the growth, yield and irrigation water productivity of a dry seeded rice-wheat cropping system in north-west India. - Field Crops Res 196: 219-36.

[23] Hobbs, P. R., Singh, Y., Giri, G. S., Lauren, J. G., Duxbury, J. M. (2002): Direct Seeding and Reduced Tillage Options in the Rice-Wheat Systems of the Indo-Gangetic Plains of South Asia. - In: Pandey, S., Mortimer, M., Wade, L., Tuong, T. P., Hardy, B. (eds.) Direct Seeding in Asian Rice Systems: Strategic Research Issues and Opportunities. International Rice Research Institute, Los Banos, Philippines, pp. 201-205.

[24] Holanda, F., Mengel, D., Paula, M., Carvaho, J., Bertoni, J. (1998): Influence of crop rotations and tillage systems on phosphorus and potassium stratification and root distribution in the soil profile. - Comm Soil Sci Plant Anal 29: 2383-94.

[25] Holloway, R. E., Dexter, A. R. (1991): Tillage and compaction effect on soil properties, root growth and yield of wheat during drought in a semi-arid environment. - Soil Tech 4: 233-53.

[26] Ishaq, M., Hassan, A., Saeed, M., Ibrahim, M., Lal, R. (2001): Sub soil compaction effects on crops in Punjab, Pakistan. I. Soil physical properties and crop yield. - Soil Till. Res. 59: 57-65.

[27] Jabro, J. D., Stevens, W. B., Evans, R. G., Iversen, W. M. (2009): Tillage effects on physical properties in two soils of the Northern Great Plains. - Appl Eng Agric 25: 37782. 
[28] Kamra, S. K., Khajanchi, L., Singh, O. P., Boonstra, J. (2002): Effects of pumping on temporal changes in groundwater quality. - Agric Water Manage 56: 169-78.

[29] Laddha, K. C., Totawat, K. L. (1997): Effects of deep tillage under rainfed agriculture on production of sorghum (Sorghum biocolor L. Moench) intercropped with green gram (Vigna radiate L. Wilczek) in western India. - Soil Till Res 43: 241-50.

[30] Lampurlanes, J., Cantero-Martinez, C. (2003): Soil bulk density and penetration resistance under different tillage and crop management systems and their relationship with barley root growth. - Agron J 95: 526-36.

[31] Mosaddeghi, M. R., Mahboubi, A. A., Safadoust, A. (2009): Short-term effects of tillage and manure on some soil physical properties and maize root growth in a sandy loam soil in western Iran. - Soil Till Res 104: 173-179.

[32] Naklang, A. K., Fukai, B. S., Nathabut, A. K. (1996): Growth of rice cultivars by direct seeding and transplanting under upland and lowland conditions. - Field Crops Res. 48: 115-123.

[33] Osunbitan, J. A., Oyedele, D. J., Adekalu, K. O. (2005): Tillage effects on bulk density, hydraulic conductivity and strength of a loamy sand soil in southwestern Nigeria. - Soil Till Res 82(1): 57-64.

[34] Prasad, S. L., Balanagoudar, S. R. (2017): Soil quality assessment in selected dry direct seeded rice and puddled paddy field in agro climatic zone 2 of Northern Karnataka. - Int J Pure Appl Biosci. 5(3): 362-368.

[35] Reynolds, W. D., Elrick, D. E., Youngs, E. G. (2002): Single-Ring and Double or Concentric-Ring Infiltrometers. - In: Dane, J. H., Topp, G. C. (eds.) Methods of Soil Analysis. Soil Sci Soc Am, Madison, WI, pp. 821-26.

[36] Saleh, A. F. M., Bhuiyan, S. I. (1995): Crop and rainwater management strategies for increasing productivity of rainfed lowland rice systems. - Agric. Syst. 49: 259-276/

[37] Schnier, H. F., Dingkuhn, M., DeDatta, S. K., Mengel, K., Faronilo, J. E. (1990): Nitrogen fertilization of direct seeded flooded vs. transplanted rice. I. Nitrogen uptake, photosynthesis, growth, and yield. - Crop Sci. 30: 1276-1284.

[38] Sharma, P. K., Ladha, J. K., Bhushan, L. (2003): Soil Physical Effects of Puddling in Rice-Wheat Cropping Systems. - In: J. K. Ladha, J. E. Hill, J. M. Duxbury, R. K. Gupta, and, R. J. Buresh (eds.) Improving the Productivity and Sustainability of Rice-Wheat Systems: Issues and Impacts. ASA, CSSA, SSSA, Madison, WI. ASA Special Publication 65: 97-113.

[39] Sharma, S. K., Tomar, R. K., Gangwar, K. S. (1995): Effects of crop establishment and tillage practices on yield and economics of irrigated rice (Oryzasativa)-wheat (Triticum aestivum) system. - Ind. J. Agric. Sci. 65: 636-638.

[40] Sharma, S. K., Pandey, D. K., Gangwar, K. S., Tomar, O. K. (2005): Effect of crop establishment methods on performance of rice (Oryzasativa) cultivars and their effects on succeeding wheat (Triticum aestivum). - Ind J. Agron. 50: 253-255.

[41] Sojka, R. E., Home, D. J., Ross, C. W., Baker, C. J. (1997): Subsoiling and surface tillage effects on soil physical properties and forage oat stand and yield. - Soil Till Res 40: 12544.

[42] Srinivasa Prasad, L., Balanagoudar, S. R. (2017): Soil quality assessment in selected drydirect seeded rice (dry-dsr) and puddled paddy fields in agro climatic zone 2 of northern Karnataka. - Int. J. Pure App. Biosci. 5(3): 362-368.

[43] Strudley, M. W., Green, T. R., Ascough, J. C. (2008): Tillage effects on soil hydraulic properties in space and time. - Soil Till Res 99: 4-48.

[44] Tuong, T. P., Singh, A. K., Siopongco, J. D. L. C., Wade, L. J. (2000): Constraints to high yield of dry-seeded rice in the rainy season of a humid tropic environment. - Plant Prod. Sci. 3: 164-172.

[45] Varsa, E. C., Chong, S. K., Abolaji, J. O., Farquhar, D. A., Olsen, F. J. (1997): Effect of deep tillage on soil physical characteristics and corn (Zea mays L.) root growth and production. - Soil Till Res 43: 219-28. 
[46] Velykis, A. (2004): Effect of subsoiling on agrophysical properties of compacted clay loam soil. Subsoil compaction-distribution, processes and consequences. - Adv Geoecol 32: 325-30.

[47] Wang, H. Q., Bouman, B. A. M., Zhao, D. L., Wang, C., Moya, P. F. (2002): Aerobic Rice in Northern China: Opportunities and Challenges. - In: Bouman, B. A. M., Heengsdijk, H., Hardy, B., Bindraban, P. S., Tuong, T. P. and Ladha, J. K. (Eds.). Proc of the International Workshop on Water Wise Rice Production, 8-11 April 2002, IRRI, Los Banos, Phillipines, pp. 143-54.

[48] Wang, J. D., Gong, S. H., Sui, J., Xu, H., Yu, Y. D. (2008): Effects of drip irrigation frequency on the farmland soil water-heat distribution and spring maize growth in North China. - Trans Chinese Soc Agric. Engg. 24: 39-45.

[49] Zhang, S. H., Li., S. K. (2010): Domestic and Foreign Corn Industrial Technology Development Report. - China Agricultural Science and Technology Press, Beijing. 